\title{
Elżbieta Konończuk
}

Uniwersytet w Białymstoku

\section{Podlaska lokalność w narracjach socjologicznych, magicznych i satyrycznych}

Nowy regionalizm jest zjawiskiem ożywionym za sprawą zwrotu przestrzennego, który wygenerował zainteresowanie konkretnym miejscem geograficznym na mapie zdecentralizowanej w wyniku globalizacji. Zainteresowanie to skonkretyzowało się $\mathrm{w}$ wielu tekstach literackich dających artystyczny wyraz doświadczeniom przestrzeni marginalnych, pogranicznych, czy też małych miejsc położonych na peryferiach wielkiej kultury, miejsc, które dzięki temu, że zostają utekstowione, a przez to ujęte $\mathrm{w}$ system semiotyczny, nabierają charakteru miejsc kulturowych. W dyskursie nowego regionalizmu ważne stają się zatem lokalność i sposoby jej artykułowania, czyli narracje lokalne, które pełnią zarazem funkcję narracji tożsamościowych. Przedmiotem moich rozważań będą podlaskie narracje lokalne jako przykład przemian w sposobie myślenia o konkretnym miejscu. Zwrot przestrzenny wpłynął bowiem zarówno na zmiany $w$ tematyce literackiej, jak i na odnowę narzędzi interpretacji literaturoznawczej, wprowadzając nowe kategorie opisu z zakresu geopoetyki, umożliwiające przedstawianie relacji między konkretnym miejscem w porządku geograficzno-historycznym a doświadczającym je człowiekiem. Doświadczenie miejsca, zawsze usytuowanego w jakimś regionie - szczególnie miejsca małego, oddalonego od centrum - warunkowane jest przemianami zachodzącymi w relacjach między tym, co regionalne, a tym, co uniwersalne. Lokalność zatem jest zjawiskiem historycznie zmiennym, a w konsekwencji zmienia się także sposób jej przedstawienia $\mathrm{w}$ literaturze. 
Kategorię małych narracji lokalnych przyjmuję z jednej strony za filozoficzną koncepcją Jeana-Françoisa Lyotarda, z drugiej zaś za teoretycznoliterackimi propozycjami Ingi Iwasiów i Michała Głowińskiego. Lyotard rozumie „małe narracje” jako konsekwencję rozpadu „wielkich narracji”, czyli dawnego porządku geopolitycznego. Są to więc opowieści prowadzone przez tych, którzy wyszli spod szeroko rozumianej dominacji i mają potrzebę zabrania głosu w sprawie swojej nowej historii i nowej przestrzeni ${ }^{1}$.

Inga Iwasiów pisze o narracjach lokalnych jako geoliterackich tekstach, które są zapisem osobistego doświadczenia konkretnego miejsca ${ }^{2}$. Pisarze coraz częściej i chętniej eksplorują swoje prywatne przestrzenie, szczególnie te, które były nieobecne w dyskursie dominacji. Kariera narracji małych miejsc żeby wspomnieć o klasykach formy, Piotrze Szewcu, Andrzeju Stasiuku, Arturze Danielu Liskowackim, Jerzym Limonie - wiąże się także z ich awansem, gdyż dzięki artystycznemu sportretowaniu miejsca te stają się medium między regionalnością a uniwersalnością. Natomiast Głowiński małymi narracjami nazywa te utwory Mirona Białoszewskiego, które postrzega jako „programowo sprozaizowane, potoczne, ucodziennione", jako relacje z błahych wydarzeń, które „dzieją się na niewielkich - zwykle dających się wskazać na mapie - przestrzeniach Warszawy bądź w miejscowościach podstołecznych, Otwocku, Garwolinie czy Mińsku" ${ }^{3}$. Historie osadzone przez Białoszewskiego w codzienności mają za zadanie wprowadzić w obręb wielkiego pisarstwa małe formy i tematy, które zazwyczaj funkcjonują na marginesach czy peryferiach oficjalnej kultury.

Obecność podlaskich narracji w recepcji nie tylko lokalnej publiczności jest dobrym przykładem przesunięcia uwagi pisarzy i krytyków ku obrzeżom, pograniczom, marginesom, miejscom oddalonym od centrum. Przedmiotem moich rozważań są wybrane przykłady prozy powstałej na Podlasiu, które oddają przemiany w sposobie literackiej konstytucji miejsca w zależności od konwencji artystycznej oraz rozumienia zjawiska regionalizmu. Za reprezentatywne dla przełomu lat sześćdziesiątych i siedemdziesiątych można uznać zbiory opowiadań Edwarda Redlińskiego Listy z Rabarbaru (1967) i So-

1 Zob. J.-F. Lyotard, Kondycja ponowoczesna. Raport o stanie wiedzy, przeł. M. Kowalska i J. Migasiński, Warszawa 1997.

2 I. Iwasiów, Inna uległość. Trudne początki szczecińskiej lokalności, w: Narracje po końcu (wielkich) narracji. Kolekcje, obiekty, symulakra..., red. H. Gosk i A. Zieniewicz, Warszawa 2007.

3 M. Głowiński, Małe narracje Mirona Białoszewskiego, w: tegoż, Gry powieściowe. Szkice z teorii $i$ historii form narracyjnych, Warszawa 1973, s. 320. 
krata Janowicza Wielkie miasto Białystok (1973), które realizują poetykę dokumentu, wpisując się zarazem w wiejski nurt literatury tematyzujący awans społeczny. Opowiadania te przedstawiają i diagnozują w aspekcie psychosocjologicznym zachowania typowe w sytuacji przeprowadzki ze wsi do miasta. Redliński w swoim debiutanckim zbiorze ukazuje konflikt pokoleń: młodych uciekających do miasta, do pracy w fabryce, do nauki oraz starych, którzy godnie służą ziemi, pokornie znosząc politykę państwa nieprzychylną indywidualnym rolnikom. Marzenia o odległych, obcych i na pewno lepszych miejscach podsycane są $\mathrm{w}$ opowiadaniu Brzozy rytualnym wspinaniem się młodego bohatera na drzewo, z którego podgląda daleki świat:

Widać wielką dolinę, coś jakby łąki nad rzeką. To chyba Narew. A ta wieża, co miga w dni najsłoneczniejsze, to chyba kościół. Co to za kościół. Może suraski. Może łapski. A może to Pałac Kultury w samej Warszawie? Nie, to niemożliwe, za daleko do Warszawy. Nigdy nie byłem w Warszawie. Co to właściwie za miasto. Tyle się o niej pisze. Grzesiek Dąbrowski studiuje w Warszawie. Opowiada, że w Warszawie ludzie są delikatniejsi w obejściu, na wyższym poziomie. Chyba ucieknę do Warszawy ${ }^{4}$.

W opowiadaniu List piętnastolatek zwraca się z prośbą do „Redakcji i Partii" o pomoc w dostaniu się do szkoły w mieście, a przedstawiona przez niego argumentacja, uzasadniająca konieczność ucieczki ze wsi, ilustruje wszystkie ówczesne problemy społecznej i ekonomicznej nierówności, wynikające z zamieszkiwania gorszych miejsc. Zbiór Redlińskiego, oprócz treści socjologicznych, zawiera także liryczne i pełne pokornego smutku obrazy wsi. Oto ojciec bohatera, starzec dumny z tego, że jest przypisany ziemi, zwiedza z synem muzeum rolnicze i nie może się nadziwić, że sprzęt "całkiem do rzeczy”, który powinien być dostępny w sprzedaży i pracować w polu, jest wystawiony na pokaz. Dramat chłopa, który uświadamia sobie, że jest powoli spychany do roli mieszkańca skansenu, oddaje cytat:

Zaraz za progiem stoją w sieni stare ule i kołowrotki, wiszą lampy naftowe, leżą żarna, rozkracza się stara sieczkarnia. Ojciec zatrzymał się przed nią, palce mu się zaruszały. Nachylił się, zajrzał, pomacał. Nauczyciel sprawujący tego dnia rolę kustosza delikatnie zwrócił uwagę: Eksponatów dotykać nie wolno... [...] Ojciec był wstrząśnięty. Z początku hamował się. Potem chodził wzdłuż ścian z opuszczonymi rękami i gubił łzę za łzą. [...] Do domu zajechaliśmy na wieczór. [...] Mój stary chodził po gumnie jak błędny. [...] poszarzał jakoś, głowę wcisnął w barki. [...] Uważnie przyglądał się wyłysiałym strzechom, koślawym węgłom, zbutwiałym drzwiom. I powiedział jedno słowo, bezgranicznie smutne: Esponaty... ${ }^{5}$.

4 E. Redliński, Listy z Rabarbaru, Warszawa 2007, s. 28.

5 Tamże, s. 80. 
Przykładem liryczności prozy Redlińskiego jest opowiadanie Ojciec, a szczególnie wzruszająca scena, w której ojciec narratora po wyjściu z kościoła, widzi swoją Siwkę pokrytą lodem. Najpierw okrywa konia swoim kożuchem, potem fufajką, potem kożuchem syna i tak obaj w trzaskającym styczniowym mrozie, jeden w koszuli, drugi w marynarce, docierają do domu. W tym samym opowiadaniu wzrusza obraz ojca, który podtrzymuje zakrwawionego konia, podnoszącego się z kolan po upadku na oblodzonej drodze. Zdarzenie to przedstawia w liście do Redakcji, rysując w skupieniu, drżącą ręką konia klęczącego w kałuży krwi i uzupełniając rysunek wierszem, w którym zanosi skargę na spółdzielnie GS zaopatrzone w alkohol, ale nie $\mathrm{w}$ hacele do podków. W zamieszczonej w gazecie odpowiedzi na list Józefa Kosego ze wsi Rabarbar, Redakcja wyraziła nadzieję, że „handel wyjdzie naprzeciw potrzebom klienta wiejskiego". W prozie Redlińskiego często liryczność splata się z dokumentalnością, jak poezja świata z jego prozą. Prostota bohaterów, których przeznaczeniem jest opieka nad ziemią pozostawioną im przez przodków, przejawia się w ich naiwnej wierze, że podobnie jak oni troszczą się o swój dobytek, o nich troszczą się władze państwowe. Listy pisane do Redakcji z Rabarbaru są wyrazem nie tylko nadziei, jaką mieszkańcy wsi żywią wobec władzy, ale także potrzeby mówienia własnym głosem, toteż stanowią szczególnie ciekawy przykład narracji lokalnych.

Proza Janowicza lat siedemdziesiątych także pełni funkcję dokumentu społecznego, będącego $\mathrm{z}$ jednej strony zapisem obserwacji wielkomiejskiej przestrzeni, z drugiej zaś diagnozą wyludniającej się wsi. Tematem jego prozy jest Białystok kształtujący się jako urbanistyczna hybryda, zagarniająca i włączająca w swój krwiobieg tereny wiejskie. W takim mieście splata się doświadczenie „miejskości” i „wiejskości”, co zabawnie ukazuje opowiadanie Miasto. Narrator, chłop, który codziennie, chcąc dotrzeć na swoje pole, przedziera się furmanką przez ruchliwe ulice miasta, tak oto opisuje swoją miejsko-wiejską białostocką codzienność:

Za gumnem zaczyna się śródmieście. Dzwonienie tramwajów płoszy klacz. Bułankę. Spaliny przenikają przez wszystkie pory, drapią w gardle. [...] Z klepiska wjeżdżam na plac Centralny. Zza gromady limuzyn wysunął się traktor. Pyka i prycha, śmieje się drań z Bułanki. [...] Akurat zapaliło się zielone światło na skrzyżowaniu dwóch arterii koło Iwanowego obejścia ${ }^{6}$.

Miniatury Janowicza, które przyjmują charakter małego reportażu, felietonu czy też prozy poetyckiej, przedstawiają miasto jako scenę codzien-

\footnotetext{
6 S. Janowicz, Miasto, przeł. W. Woroszylski, w: tegoż, Wielkie miasto Białystok, Warszawa 1973, s. 66-67.
} 
nych dramatów z udziałem mieszkańców i przyjezdnych. W opowiadaniu Wielkie miasto Biatystok bohater, lubiący - niczym Baudelaire'owski flâneur przypatrywać się ulicy, jest wnikliwym obserwatorem miejskiego spektaklu? Zachowania mieszkańców Białegostoku zdradzają ich wiejskie pochodzenie, które wyłania się spod pielęgnowanej przez nich nowej, miejskiej fasady.

Miasto, zamieszkane w dużej mierze przez przybyszów z okolicznych wsi, przedstawione jest $\mathrm{w}$ prozie Janowicza jako przestrzeń doświadczana przez pryzmat tęsknoty i smutku. W opowiadaniu pt. Pewnego dnia chłopak z Krynek - rodzinnej miejscowości pisarza - lubi przechadzać się w okolicach dworca autobusowego. Prowadzi go tu - gdzie często żegnał ojca lub czekał na jego przyjazd - niezrozumiałe dla niego poczucie pustki. Obserwuje ludzi, którzy wracają na wieś po załatwieniu w mieście różnych spraw, i tych, którzy wracają do miasta po odwiedzinach na wsi, rozpoznając w nich siebie sprzed lat. Bohater tego opowiadania jest typowym dla prozy Janowicza melancholikiem żyjącym w ciągłej tęsknocie za światem, z którego się wywodzi.

Opowiadanie Spacer na peryferiach miasta stanowi małą narrację o funkcji obserwacji socjologicznej, której pisarz poddaje peryferyjną dzielnicę willową, zamieszkaną przez ludzi „,zmęczonych dorabianiem się". Bohater przechadza się ulicami o miło brzmiących nazwach - Uroczą, Kwiecistą, Jagodową - podglądając młodych ludzi bawiących się w przydomowych ogrodach, „wymęczonych" - jak zauważa - dobrobytem, który ich rodzice przypłacili zdrowiem.

Przywołane tu małe formy narracyjne Janowicza przedstawiają sytuacje banalne, będące fragmentem codziennego życia miasta. Swoje miniatury epickie pisarz nazywa sokratkami, co - jak można zauważyć na podstawie przywołanych tu przykładów - stanowi nawiązanie nie tylko do imienia pisarza, ale też do idei przechadzek Sokratesa po mieście. W bohaterach prozy Janowicza można rozpoznać autoportret pisarza, który jako spacerowicz-myśliciel - niczym Sokrates zaczepiający napotkanych na ulicy ludzi, aby rozmawiać $\mathrm{z}$ nimi o życiu społecznym $-\mathrm{z}$ banalnych zdarzeń czyni temat opowieści, poddając refleksji zmiany zachodzące w rzeczywistości.

O regionalnym charakterze omawianych tu utworów stanowią w przypadku Redlińskiego głównie toponimie, a w przypadku Janowicza także fakt, że pisze on $\mathrm{w}$ języku białoruskim. Jednakże $\mathrm{w}$ twórczości obu pisarzy po-

\footnotetext{
7 O motywie ulicy w prozie białostockiej pisałam w artykule Białostockie pasaże tekstowe Sokrata Janowicza, Krzysztofa Gedroycia i Ignacego Karpowicza, w: Podlasie w literaturze - literatura Podlasia (po 1989 roku). Nowoczesność - regionalizm - uniwersalizm, red. M. Kochanowski, K. Kościewicz, Białystok 2012.
} 
brzmiewa - typowy dla wschodnich terenów - resentyment wiążący się z głęboko zakorzenionym, gospodarczo warunkowanym, kompleksem niższości, wynikającym z poczucia bycia skazanym na gorsze życie w miejscu kategorii $\mathrm{B}$. Małe narracje, oparte na anegdocie, epizodzie, konkrecie biograficznym czy krajobrazowym, najlepiej pokazują małe sprawy zwykłych ludzi, dziejące się $\mathrm{w}$ nasyconym melancholią krajobrazie Podlasia.

Roch Sulima w pracy wydanej w 1982 roku Literatura a dialog kultur podejmuje próbę diagnozy sytuacji literatury regionalnej w okresie, z którego pochodzą omówione utwory. Literaturę wyrastającą - jak pisze $-\mathrm{z}$ potrzeby „własnego" słowa, badacz nazywa „w przybliżeniu: regionalną" ${ }^{8}$. Za główny problem utrudniający badania nad literaturą regionalną uważa wyeksploatowany język opisu zjawisk, znoszący granice omawianych faktów, takich jak: literatura regionalna, folklorystyczna, środowiskowa, lokalna ${ }^{9}$. Określenia te stosowane są zatem wymiennie jako kwalifikacje literatury o charakterze niecentralnym i nieuniwersalnym. Badacz zauważa, że krytyka literacka $\mathrm{w}$ omawianym przez niego okresie przedstawia literaturę regionalną wobec centralnej w takich relacjach jak "niższa" i "fragmentaryczna” wobec „wyższej” i „całościowej”. W sytuacji centralistycznej i integracyjnej polityki kulturalnej państwa małe narracje o małych miejscach i zwykłych ludziach miały odbiór jedynie lokalny. Głos „centrum” reprezentuje na przykład Włodzimierz Maciąg, który w recenzji powieści Andrzeja Pastuszka tak pisał o literaturze powstałej z kompleksów pisarzy „,skazanych na miejsce":

niepotrzebna wiedza socjologiczno-środowiskowa, jaką nas niejako szantażują pisarze ze środowiskowym pochodzeniem i zapleczem w rodzaju Redlińskiego. Tacy pisarze lubią nas straszyć obietnicami, że wszystko, co wiemy o świecie, zblednie, kiedy nam odkryją tajemnice swego środowiska ${ }^{10}$.

Jako przykład reprezentatywny dla nowego regionalizmu proponuję refleksję nad najnowszymi utworami na rynku podlaskim: Michała Androsiuka Wagonem drugiej klasy (2010) i Białym koniem (2011) oraz Jana Kamińskiego Książka meldunkowa (2011).

\footnotetext{
8 R. Sulima, Literatura a dialog kultur, Warszawa 1982, s. 143.

9 Tamże, s. 130-132.

10 W. Maciąg, Żywioł, „Nowe Książki” 1977, nr 22, s. 44.
} 
Akcja prozy Androsiuka usytuowana jest w przygranicznych miejscowościach na skraju Puszczy Białowieskiej, przy granicy z Białorusią, na obrzeżach Europy. Bohaterem Wagonu drugiej klasy jest kasjer na małym dworcu najdalej na wschód wysuniętej stacyjki. Wpatrzony w peron, na który rzadko przyjeżdżają pociągi z nielicznymi pasażerami, snuje opowieści o niezwykłych przygodach zwykłych mieszkańców miasteczka. Bohaterem i narratorem Biatego konia natomiast jest mieszkaniec Miasteczka, nad którym - jak mówi - "zawsze stał cień puszczy i zapach żywicy"11. Narrator odtwarza, dzięki przechowanym przez trzy pokolenia opowieściom rodzinnym, historię Miasteczka, którego pierwowzorem jest rodzinne miejsce autora, Hajnówka. Proza Androsiuka doskonale pokazuje mechanizm funkcjonowania pamięci komunikatywnej, stanowiącej podstawę tożsamości mieszkańców małych miejsc.

Niezwykłość doświadczeń ludzi zamieszkujących miejsca tak małe, że oznaczone najmniejszym punktem na najdokładniejszych mapach, wiąże się najczęściej z ich epizodycznym kontaktem $\mathrm{z}$ wielkim, tajemniczym światem. Motyw ten jest obecny $\mathrm{w}$ omawianych tu narracjach lokalnych tematyzujących przestrzeń podlaską jako marginalną, położoną na obrzeżach mapy, oddaloną od centrum, o której świat przypomina sobie wówczas, gdy włodarze na nowo dzielą między sobą terytoria lub wysyłają ludzi na wojnę. Taką opowieść o dziadku bohatera Wagonu drugiej klasy przechowuje rodzinna pamięć:

Więc dziadek Ściopka, który jak i jego ojciec przymierzał się do szewskiego rzemiosła, odłożył szydło i zamyślił się. Nic wprawdzie nie wiedział o problemach Mikołaja Drugiego Romanowa, skoro jednak okazał się w tej wojnie potrzebny od zaraz, miała to być sprawa szczególnej wagi. Na tę okoliczność car Mikołaj podciągnął do osady jeszcze jedną linię kolejową, a gdy ostatnia szyna ułożyła się na swoim miejscu i stalowa nitka spięła Siedlce, Hajnówkę i Władywostok, pradziadek Hryszka wsadził dziadka Ściopkę do pociągu, wrzucił do wagonu tobołek z butami wyfasowanymi na tę okoliczność ${ }^{12}$.

Wojna - dzięki której władcy przypominają sobie o swoich poddanych i upominają się o nich - sprawia, że dziadek Ściopka, mieszkaniec małej wsi na skraju puszczy, staje się obywatelem świata. Ważne wydarzenia historyczne zapisują bowiem, chociaż na krótko, małe miejsca na mapie świata.

W opowiadaniu otwierającym zbiór pt. Biały kon tematem jest niezwykłe zdarzenie, przechowywane w opowieści mieszkańców wsi Opaka Duża,

11 M. Androsiuk, Biały koń, Białystok 2011, s. 37.

12 M. Androsiuk, Wagon drugiej klasy, Białystok 2010, s. 9. 
położonej przy samej granicy z Białorusią. Opowieść ta powraca w pamięci narratora za każdym razem, kiedy zbliża się on do owej przygranicznej wsi. Stanowiący granicę pas zoranej ziemi przypomina o zdarzeniu, jakie miało miejsce po zakończeniu drugiej wojny światowej, kiedy żołnierze uzbrojeni w słupy, łopaty, karabiny i mapę pojawili się we wsi, aby wytyczyć granicę państwową:

Dziś już nikt nie wie, jak i dlaczego największe w świecie imperium dotarło do maleńkiej wioseczki o nazwie Opaka Duża, a potem liznąwszy językiem stodołę Andreja Sawczuka, nie schrupało jej, nie połknęło, tylko zatrzymało się, właśnie tutaj, rozgraniczając świat na polski i ruski. [...]

- Granica tu będzie, towarzyszu rolniku.

- Granica? Jaka granica?

- Normalna, państwowa. Polsko-sowiecka.

- Jak to tak? Między domem a stodołą granica?

Iwaniuk zaprzestał pracy. Patrzył na kapitana, a doświadczenie poprzednich pokoleń podpowiadało, że wraz z mundurami nadchodzi coś obcego, niezrozumiałego i groźnego. Uciekając od wzroku Iwaniuka, kapitan jeszcze raz zagłębił się $\mathrm{w}$ tajemniczą mapę.

- Tak się złożyło, że żyć będziesz w Sowieckim Sojuzie, a po siano przyjdzie ci chadzać do Polski ${ }^{13}$.

Każdy przyjazd do Opaki Dużej przypomina narratorowi zdarzenie pielęgnowane przez lokalną pamięć zbiorową, którego bohaterem był Iwaniuk, właściciel gospodarstwa przedzielonego granicą polsko-sowiecką. W wyobraźni narratora rozgrywa się scena, w której gospodarz Kremla przygląda się ogromnej mapie wiszącej na ścianie i pyta o Opakę kapitana, który - przekupiony przez Iwaniuka słoniną, miodem i bimbrem - obiecał przeprowadzić granicę tak, aby i dom, i stodoła chłopa znalazły się w granicach Polski. Prywatna wojna Iwaniuka o jego małe terytorium z władcą imperium, który za pomocą linijki i ołówka ustala przebieg granic, skończyła się wprawdzie pozostawieniem domu $\mathrm{w}$ granicach państwa polskiego, chociaż zanim decyzja z Kremla dotarła, chłop zdążył już rozebrać dom, aby przenieść go w pobliże stodoły.

Tematem prozy Androsiuka jest $\mathrm{w}$ istocie małe miejsce postrzegane - w perspektywie czasu historycznego - jako fragment świata, natomiast $\mathrm{w}$ perspektywie czasu mitycznego jako fragment kosmosu. Wielowymiarowa czasoprzestrzeń - realizująca się przez nielinearny bieg wydarzeń sytuowanych $\mathrm{w}$ różnorodnych porządkach: fikcyjnym, historycznym, mitycznym, onirycznym - pozwala włączyć omawiane opowiadania w nurt realizmu ma-

13 M. Androsiuk, Biały koń, s. 6, 9. 
gicznego ${ }^{14}$. W opowiadaniu Europa $\mathrm{z}$ tomu Wagon drugiej klasy wydarzenie historyczne, jakim jest wejście do Unii Europejskiej, przedstawione zostało - w poetyce reportażowo-satyryczno-baśniowej - jako przyjazd Europy na małą stacyjkę w Puszczy Białowieskiej:

Przez wiele lat Europa przyjeżdżała do nas późną wiosną i odjeżdżała wczesną jesienią. Ale którejś zimy stało się jasne, że przyjedzie i zostanie z nami na zawsze. [...]

- Za kilka dni będziemy w Europie - uroczystym i lekko drżącym głosem zaczął pan naczelnik, podszedł do mapy i zakreślił wskazówką wielkie koło od Puszczy Białowieskiej po Lazurowe Wybrzeże - właśnie tu będziemy ${ }^{15}$.

Charakterystyczne dla metaforyki przestrzennej w prozie Androsiuka są obrazy, w których małe, marginalne miejsce ukazane jest w relacjach z miejscami ważnymi, centralnymi. W tej metaforyce - stanowiącej literacki język dyskursu postzależnościowego - relacje między małym miejscem i wielkim światem wyobrażone są poprzez gesty przyciągania i odpychania, zagarniania i separowania. Świat bohaterów, wyobrażony przez metaforę „wagonu drugiej klasy", jest od czasu do czasu przez historię wtaczany na szyny. Stacyjka otwiera się na wielką przestrzeń lub zamyka w zależności od uwarunkowanego polityczno-ekonomicznie otwierania lub zamykania prowadzących do niej linii kolejowych. Metaforyka przestrzenna służy nie tylko oddaniu historycznych relacji między miejscem położonym na obrzeżach puszczy a dalekim światem, ale też włączeniu tego miejsca w porządek kosmiczny, co pozwala interpretować je w wymiarze magicznym:

Mogę siedzieć tak od rana do wieczora, patrzę na tory, czekam, aż zza zakrętu wynurzy się osobowy z Czeremchy, lub z Cisówki. Nieważne skąd. Czekam i wiem, że z przyjazdem tego pociągu nie zdarzy się nic nadzwyczajnego. [...]

Kiedyś, jak wszyscy chłopcy, mogłem sobie uklęknąć na pokładach między szynami, mogłem przyłożyć ucho do stalowej struny i nasłuchiwać. Słyszałem ten oddech, oddech pociągu, dobiegający z Białowieży, i z Narewki, i miałem wrażenie, że kolejowe szyny zawiązują cały świat w jeden wielki tobołek, a słońce zarzuca go na plecy i wędruje od jednej galaktyki do drugiej ${ }^{16}$.

\footnotetext{
14 Według Katarzyny Mroczkowskiej-Brand właśnie wielowymiarowość przedstawionej przestrzeni i czasu jest jedną z technik narracyjnych typowych dla realizmu magicznego. Inne cechy, analizowane przez badaczkę, także znajdują realizację w prozie Androsiuka. Zob. K. Mroczkowska-Brand, Przeczucie innego porządku. Mapa realizmu magicznego w literaturze światowej XX i XXI wieku, Kraków 2009, s. 189.

15 M. Androsiuk, Wagon drugiej klasy, s. 102-103.

16 Tamże, s. 35.
} 
Magia przygranicznego świata przedstawiona jest także przez nadanie codziennemu życiu cech niecodziennych, co stanowi ważną cechę realizmu magicznego ${ }^{17}$. Dziadek i ojciec bohatera Wagonu drugiej klasy są szewcami, naprawiają buty, które niczym książki opowiadają im swoje historie i są pretekstem do snucia opowieści o ich właścicielach, uczestniczących w mniej lub bardziej ważnych dla świata wydarzeniach. Szewc z małego miasteczka tak widzi swój udział w porządku świata:

- Świat wszędzie taki sam. I tu drzewa, i tam drzewa. [...] Wszystkie drogi mają zamknięty kształt koła. Tylko ludzie nie chcą w to uwierzyć i szukają, czego nie zgubili - mruczy sam do siebie, czytając zdarte podeszwy. I jeszcze solidniej podbija obcasy, i zszywa podeszwy na amen, jakby wszystkie te odnowione kamasze, kozaki i pantofelki miały do niego wrócić tylko jedną drogą - po obiegnięciu kuli ziemskiej ${ }^{18}$.

W butach naprawianych przez ojca idą pielgrzymi: prawosławni na Grabarkę, katoliccy do Częstochowy. Nosi je ksiądz Ignacy i batiuszka Michaił. Narrator mówi więc: „Tak właśnie przechodzi się do historii w małych miastach - trwając w jednym miejscu i tworząc rzeczy niekoniecznie piękne, ale przydatne wszędzie i każdemu" ${ }^{19}$. Autor ukazuje zwyczajność małomiasteczkowego życia szewców uniezwykloną przez historie tych, którzy w zrobionych przez nich butach przemierzają świat. Barwny akcent do codzienności małego miejsca wnosi inny bohater, stryj narratora, bliźniak ojca, który wyrusza w świat w poszukiwaniu przedmiotu swojej fascynacji, żyrafy. Androsiuk jest mistrzem przekształcania nie tylko niebanalnych, ale też szarych historii rodzinnych - jak ma to miejsce w Białym koniu - w przypowieści, które są szczególnie ważne dla trwania pamięci komunikatywnej małej społeczności.

Realizm magiczny omawianej prozy, podnoszący rangę lokalności, przejawia się także w odnoszeniu fabuły do wiecznie teraźniejszego mitycznego czasu. Tym samym losy ludzkie przedstawiane są już nie tylko jako uwikłane historycznie, ale też jako włączone w kosmiczny porządek. Dziadek Ściopka został wpisany do historii, ponieważ car uwiecznił jego los na papierze, a starosta odczytał go, uroczyście rozwijając i zwijając rulon. Jednakże w leśnej osadzie wszyscy wiedzą, że „Pan Bóg zapisuje ludzkie losy w gwiazdach, panowie przepisują je $z$ gwiazd na papier, a potem odczytują - gromadnie, lub każdemu z osobna" ${ }^{20}$.

\footnotetext{
17 Por. K. Mroczkowska-Brand, Przeczucie innego porzadku, s. 53.

18 M. Androsiuk, Wagon drugiej klasy, s. 24.

19 Tamże, s. 25.

20 Tamże, s. 8.
} 
W nurt nowej lokalności, wynikającej ze zwrotu przestrzennego, wpisuje się także inna powieść podlaskiego twórcy, Książa meldunkowa Jana Kamińskiego. Utwór oparty jest na koncepcie odnalezionej księgi meldunkowej, prowadzonej przez jego ojca na zlecenie władzy, a zawierającej daty narodzin i śmierci mieszkańców podlaskiej wsi. Księga ta staje się pretekstem do odtworzenia portretów zapisanych $\mathrm{w}$ niej ludzi, a jednocześnie swoistą figurą pamięci, tabliczką mnemotechniczną z odciśniętymi śladami przeszłości, które pozwolą odtworzyć dzieje lokalnej społeczności. Koncept narracji poprzedzonej lekturą książki meldunkowej odsyła do toposu życia-księgi, gdyż każdy z zapisanych staje się tematem chociażby krótkiej opowieści, jak te przechowywane $\mathrm{w}$ pamięci wiejskiej społeczności. Często pozornie banalnym opowieściom portretującym zwykłych ludzi narrator nadaje niezwykłość przez włączenie w ich biografię epizodów o charakterze tajemniczym. Kamiński pokazuje mechanizm tworzenia historii lokalnej przez łączenie jej z wielką historią. Oto życie prostych ludzi - podobnych nieraz do bohaterów ludowych baśni czy legend - splata się z historią świata. Mieszkańcy podlaskiej wioski mają zatem w swojej biografii na przykład wizytę w Petersburgu u cara, czy też - jak babka Luda - pracę w burdelu w Argentynie, gdzie została uprowadzona jako emigrantka. Cechą pamięci lokalnej jest przekazywanie faktów lokalnych wzbogaconych o barwne, mitologizujące je elementy.

Obaj pisarze, Michał Androsiuk i Jan Kamiński, wpisują się w nowy regionalizm, który nadaje literaturze funkcję przechowywania pamięci lokalnej. Włączają oni strumień podlaski $\mathrm{w}$ "głębinową falę pamięci, która rozlała się ostatnio po świecie, wszędzie wiążąc ze sobą bardzo ściśle wierność dla rzeczywistej lub wyobrażonej przeszłości" - jak pisze Pierre Nora o współczesności, rozpoznawanej przez niego jako „czas pamięci” ${ }^{21}$. Rzeczywista i wyobrażona przeszłość regionu staje się $\mathrm{w}$ istocie treścią przekazu literackiego, którego funkcją jest utrwalenie wiedzy o konkretnych miejscach $\mathrm{w}$ regionie.

Przyjmując, że funkcją narracji lokalnych, oprócz przedstawienia obrazu miejsca, jest także budowanie tożsamości lokalnej, warto zastanowić się nad rolą utworów o charakterze satyrycznym. Za przykład niech posłużą dwie wybrane powieści - Edwarda Redlińskiego Awans (1973) i Ignacego Karpowi-

21 P. Nora, Czas pamięci, przeł. W. Dłuski, „Res Publica Nowa” 2001, nr 7, s. 37. 
cza Niehalo (2006) - które poprzez groteskowe wyobrażenie regionu, proponują szczególnie atrakcyjną formę estetycznego zapośredniczenia lokalności.

W powieści Awans Redliński w zdeformowanym i przejaskrawionym obrazie poddaje satyrycznemu oglądowi taką sytuację społeczną, jaka w latach siedemdziesiątych była tematem literatury nurtu wiejskiego, a wiązała się ze społecznym awansem chłopów. Jak w krzywym zwierciadle ukazana jest edukacja wiejskich dzieci prowadzona przez nauczyciela, który powraca do swojej wsi z misją cywilizowania jej mieszkańców. Autor podejmuje także ciekawy - aktualny i sytuujący się we współczesnym dyskursie turystycznym temat przekształcania się wsi w produkt wystawiany na sprzedaż mieszkańcom miasta. Ukazuje dwa modele utowarowienia wsi, odpowiadające oczekiwaniom miejskiego konsumenta, któremu jedni wieśniacy proponują luksusowe, niczym miejskie, warunki wypoczynku, inni zaś inscenizują zacofaną wieś, czyniąc siebie mieszkańcami skansenu, a w istocie aktorami ludowego spektaklu. Satyra Redlińskiego na wieś, która spełniając oczekiwania miasta, ulega komercjalizacji, odsłania absurdy przekształcania się autentycznej wiejskości w wiejskość odgrywaną.

Karpowicz natomiast kreuje bohatera „odklejonego" od rzeczywistości, mieszkańca "miasta tak niszowego, że prawie go nie widać na mapie” ${ }^{22}$, miasta, z którym jest coś niehalo. Bohater, dziennikarz „Wiadomości Podlasia", z racji swojej zawodowej funkcji przemieszcza się, a raczej plącze po mieście, znienawidzonym i postrzeganym przez pryzmat zniszczonych ulic, sypiących się budynków i nieciekawych ludzi. Miasto przypomina organizm w stanie rozkładu:

Wychodzę na ulicę Lipową. Najbardziej reprezentacyjna arteria Białegostoku. Arteria. Raczej cienka żyłka w zaawansowanej miażdżycy. Skrzep przy kościele Rocha, skrzep przy pałacu Branickich ${ }^{23}$.

To „miasto z przetrąconym kręgosłupem” 24, w którym króluje bylejakość, głupota i marazm, przedstawione jest zatem $\mathrm{w}$ poetyce oniryczno-groteskowej. Pomysł wysłania bohatera na odrealnioną przechadzkę z ożywionymi pomnikami Popiełuszki i Piłsudskiego pozwala obserwować absurdy politycznego życia miasta. W deformujących rzeczywistość i satyrycznych obrazach demaskuje autor mechanizmy zawłaszczania miejskiej przestrzeni przez różne grupy manifestujące, często agresywnie, swoje poglądy społeczne, polityczne czy religijne. Miasto, postrzegane jako psujące się i zużyte, zostaje

\footnotetext{
22 I. Karpowicz, Niehalo, Wołowiec 2006, s. 14.

23 Tamże, s. 34-35.

24 Tamże, s. 114.
} 
w symbolicznej scenie zwinięte $\mathrm{w}$ rulon przez Marszałka i jak przetarty kilim sprute i nawinięte na kłębek. W innej scenie starcia fantastycznych sił następuje apokaliptyczna zagłada, po której bohater w optymistycznym finale stwierdza: „Dziś zaczyna się świat!”.

Autorzy obu powieści przedstawiają - z wykorzystaniem estetyki groteski - te same problemy lokalne Podlasia, które znalazły odbicie w literaturze dokumentu społecznego. Awans społeczny, migracje ze wsi do miasta, kształtowanie się wielkomiejskiej przestrzeni i warunkowanych przez nią form zachowań społecznych stały się zarówno przedmiotem obserwacji socjologicznej prozy dokumentującej, jak i przedmiotem satyrycznej refleksji.

Przyjęcie przez twórców konwencji groteski służy - przeciwnie niż mitologizowanie - wyrażeniu dystansu wobec lokalnej rzeczywistości. Poddanie lokalności zdeformowanemu obrazowaniu jest efektem autoironicznego spojrzenia na miejsce, co wiąże się nie tylko z krytyką tego miejsca, ale też z troską o nie. Demaskatorskie zacięcie pisarzy - realizujące się poprzez estetykę satyry i wyrafinowaną groteskę - pokonuje kompleks prowincji, podnosząc problemy lokalne, poprzez nadanie im wyrazu wysokoartystycznego, do rangi uniwersalnych.

Wszystkie omówione wyżej utwory można odczytać jako potwierdzające rozważania Małgorzaty Czermińskiej na temat miejsc autobiograficznych $\mathrm{w}$ literaturze, czyli miejsc z odniesieniem geograficznym, których literackie wyobrażenia wiążą się z biografią autora lub ze scenerią jego utworów i które są wykładnią osobistych doświadczeń przestrzennych pisarza ${ }^{25}$. Zjawisko to jest charakterystyczne dla narracji lokalnych, przekształcających autentyczne miejsca geograficzne $\mathrm{w}$ ich kulturowe - realistyczne, groteskowe, symboliczne, metaforyczne - wyobrażenia. Narracje takie są często głosem dobiegającym z miejsc własnych pisarza, miejsc niejednokrotnie nieobecnych na literackiej mapie, niosących doświadczenie prowincji, marginalności, a przez to typowych dla tendencji określanej jako „nowa lokalność”, wpisującej się w nurt zwrotu przestrzennego. Literatura zwrotu przestrzennego - zarówno w beletrystycznej, jak i teoretycznej realizacji - tematyzuje, a tym samym waloryzuje małe miejsca, nanosząc je na mapę literackich miejsc akcji oraz na mapę życia literackiego i w ten sposób decentralizując obie.

25 M. Czermińska, Miejsca autobiograficzne. Propozycja w ramach geopoetyki, „Teksty Drugie” 2011, nr 5. 
Tematyzując miejsca usytuowane poza wielką historią wydarzeniową oraz poza uczęszczanym traktem turystycznym, pisarze ukazują ich atrakcyjność i wykorzystują pokłady pamięci lokalnej, przechowującej narracje historyczne, geograficzne i biograficzne o wydarzeniach, miejscach i ludziach. Małe narracje lokalne pełnią także funkcję narracji tożsamościowych, uczestniczących w konstruowaniu zarówno tożsamości pisarza, jak mieszkańców opisywanych miejsc. Praktykowanie pamięci komunikacyjnej bowiem stanowi podstawę tożsamości lokalnej, rozumianej jako identyfikacja z miejscem i jego przeszłością. Ważnym uczestnikiem sytuacji komunikacyjnej, której celem jest transmisja poprzez literaturę treści przechowywanych $\mathrm{w}$ pamięci lokalnej, staje się - oprócz pisarza - także badacz.

Tendencją wpisaną $\mathrm{w}$ nowy regionalizm jest wzrost zainteresowania miejscami biograficznymi pisarza, które przedstawione w jego twórczości nabierają statusu miejsc autobiograficznych. Poszukiwanie i konfrontowanie takich realnych miejsc $\mathrm{z}$ ich literackim wyobrażeniem jest podstawą rozwijającej się tak zwanej turystyki literackiej. Zainteresowanie to ma także wpływ na kształtowanie się nowych postaw czytelniczych i badawczych. Narracje lokalne wyznaczają bowiem swoisty model odbioru, odsyłając do wspólnego obszaru doświadczeń oraz pamięci zbiorowej pisarza i odbiorcy. Interpretacją literatury regionalnej najczęściej zajmują się badacze lokalni, którym nieobce jest doświadczenie miejsc przedstawionych $\mathrm{w}$ literaturze. W takiej sytuacji badacz zawiesza obiektywizujący dystans, rozpoznając $\mathrm{w}$ utworze miejsca związane $\mathrm{z}$ jego własną biografią. Tym samym do wypowiedzi naukowych dotyczących narracji lokalnych często przenikają prywatne doświadczenia badacza, mające wpływ na charakter konkretyzacji przedstawionych $\mathrm{w}$ literaturze światów. Podstawą konkretyzacji powstającej podczas odbioru narracji lokalnych mogą być bowiem miejsca autobiograficzne interpretatora.

Rybicka, przedstawiając stanowiska badaczy w kwestii relacji między podmiotem a miejscem - problem wygenerowany przez zwrot topograficzny - przywołuje poglądy Rosi Braidotti, przywiązującej wagę do "pozycji” geograficznej badacza, czy też stanowisko Roberta M. Dainotta, wiążącego lokalizację geograficzną $\mathrm{z}$ metodą badawczą i zwracającego uwagę na strategię autolokalizacyjną zarówno współczesnego twórcy, jak i badacza, którzy dawną, literacką strategię wykorzenienia czy wygnania zastąpili strategią topologiczną ${ }^{26}$. Twórca i badacz mówią bowiem z konkretnego miejsca

26 Por. E. Rybicka, Zwrot topograficzny w badaniach literackich. Od poetyki przestrzeni do polityki miejsca, w: Kulturowa teoria literatury 2. Poetyki, problematyki, interpretacje, red. T. Walas, R. Nycz, Kraków 2012, s. 334. 
i zapewne $\mathrm{w}$ tym miejscu ich wypowiedź nabiera szczególnego znaczenia, a być może nawet jest tu lepiej rozumiana. Autolokalizacja geograficzna badacza, angażująca go prywatnie w interpretację, może stanowić moment sensotwórczy.

Proces unarracyjniania miejsca - czy to przez uczynienie go przedmiotem analizy dokumentu społecznego, czy przedmiotem satyryczno-groteskowej deformacji, czy też realizmu wzbogaconego o elementy magiczne - zawsze jest sposobem „zamieszkiwania" tego miejsca i jego rozumienia. Artystycznie różnorodne, literackie reprezentacje podlaskiej przestrzeni wpisują się w ruch określany przez Kazimierza Brakonieckiego jako „wielka odnowa polskiej prowincji". Są też dobrą ilustracją zjawiska nazywanego przez niego „regionalizmem ponowoczesnym” ${ }^{27}$, z którym badacz wiąże rozwój tożsamości regionalnej oraz wzrost świadomości życia "tu i teraz", przejawiającej się otwarciem na konkret biograficzny, krajobrazowy, historyczny oraz realizującej się w poszukiwaniach genealogicznych i mitologizacji lokalności.

Omówione wyżej utwory Redlińskiego, Janowicza, Karpowicza, Androsiuka, Kamińskiego oddają poetykę podlaskiej przestrzeni, otwierając się tym samym na interpretację narzędziami geopoetyki, geografii humanistycznej i kulturowej. Wpisują się one także w obszar zainteresowania geokrytyki ${ }^{28}$, którą Elżbieta Rybicka przedstawia jako metodę badawczą zajmującą się szeroko rozumianymi interakcjami między przestrzeniami geograficznymi a ich reprezentacjami $\mathrm{w}$ literaturze $\mathrm{i}$ innych dziedzinach sztuki. W konsekwencji przedmiotem rozważań geokrytyki jest kulturowa i literacka konstytucja miejsc rzeczywistych. Utwory, o których była tu mowa, nazwałabym założycielskimi reprezentacjami małych miejsc w regionie, które dzięki tym reprezentacjom zyskały byt kulturowy, a przez to trwanie. Są potwierdzeniem sformułowanej przez Rybicką tezy głoszącej, iż literatura i miejsce potrzebują się wzajemnie. Literatura inspirowana historią i geografią konkretnego miejsca także je współtworzy. Hanna Buczyńska-Garewicz, w swojej fenomenologicznej analizie relacji człowieka i przestrzeni, podkreśla, że relacją najważniejszą jest wzajemne kształtowanie się:

\footnotetext{
27 Termin zaproponowany przez Kazimierza Brakonieckiego w artykule Ponowoczesny regionalizm, „Nowy Nurt” 1996, nr 8, s. 1.

28 Zob. E. Rybicka, Geopoetyka, geokrytyka, geokulturologia. Analiza porównawcza pojęć, „Białostockie Studia Literaturoznawcze" 2011, nr 2, s. 33-34. Geokrytyka definiuje od nowa kategorię poetyki przestrzeni, która weszła do języka literaturoznawstwa jako odnosząca się do przestrzeni intymnych, związanych z topografią domu, a która po zwrocie topograficznym realizującym się w takich dyscyplinach jak geopoetyka, geokrytyka - odnosi się do przestrzeni i miejsc rozumianych geograficznie jako konkretnie zlokalizowane.
} 
Odpowiedzialność za miejsce jest zarazem samoodpowiedzialnością ludzką. To, gdzie przebywamy, stanowi też o tym, kim jesteśmy. Jak wspomniano powyżej, miejsce i mieszkaniec współkonstytuują się wzajemnie. Jeśli człowiek tworzy sens miejsca, to także miejsce, zinterioryzowane w duszy, określa rodzaj tej duszy. A wobec braku miejsca człowiek czuje się duchowo bezdomny ${ }^{29}$.

W przypadku miejsc postrzeganych jako prowincjonalne, marginalne, generujące kompleks niższości, odpowiedzialność, jaka spada za nie na ich mieszkańców, jest szczególnie trudnym procesem. Nowy regionalizm podnosi ten problem, podkreślając rolę twórcy, który dzięki swoim artystycznym reprezentacjom miejsca, przyjmuje także odpowiedzialność za nie. Hanna Buczyńska-Garewicz stwierdza, iż efektem relacji między miejscem i jego mieszkańcem jest wzajemne współkonstytuowanie się. Kiedy tym mieszkańcem jest pisarz, to można powiedzieć - parafrazując słowa Buczyńskiej-Garewicz - że miejsce stwarza pisarza, a on poprzez swoją literaturę stwarza miejsce.

\section{Podlasie's Localness in Sociological, Magical and Satirical Narratives}

\section{Summary}

The article focuses on the local narratives of the Podlasie region as represented by Edward Redliński, Sokrat Janowicz, Michał Androsiuk, Jan Kamiński and Ignacy Karpowicz. The author presents the transformations of tendencies in the Podlasie prose of the latest half-century, from the poetics of sociological document to the poetics of grotesque and magical realism, interpreting these transformations as characteristic of new regionalism.

${ }^{29}$ H. Buczyńska-Garewicz, Miejsca, strony, okolice. Przyczynek do fenomenologii przestrzeni, Kraków 2006, s. 39. 